\title{
Gray-brown skin discoloration following phototherapy for hyperbilirubinemia due to anti-E alloimmunization
}

A female infant was born by spontaneous vaginal delivery at 40 weeks and 3 days of gestation with a birth weight of 3,500 $\mathrm{g}$ from the third pregnancy of a 38-year-old woman. The mother was G2P0A0A2 and had undergone 2 previous uncomplicated normal deliveries. Her prenatal and maternal history was unremarkable. The first 2 children are presently thriving. On the third day after delivery, this baby presented with jaundice; the total bilirubin level was 34.2 $\mathrm{mg} / \mathrm{dL}$. We started intensive phototherapy and prepared to perform an exchange transfusion to decrease the bilirubin levels. The other laboratory findings are presented in Table 1 . The mother's blood group was Rh-positive A type. Considering the aforementioned findings, indirect hyperbilirubinemia related to minor blood group incompatibility due to anti-E antibodies was diagnosed. The infant was treated with exchange transfusion and intravenous immunoglobulin and intensive phototherapy to prevent kernicterus and progression of hemolysis. Following the exchange transfusion, the total bilirubin remained elevated at $22.3 \mathrm{mg} / \mathrm{dL}$. Eight hours after continuing intensive phototherapy, progressive gray-brown discoloration of the skin was noted (Fig. 1A). This discoloration was observed in areas that were uncovered and exposed to the intensive phototherapy light (Fig. 1A). The laboratory values observed at that point are presented in Table 1.

Based on the clinical findings, what is the expected diagnosis?

(1) Gray baby syndrome

(2) Bronze baby syndrome

(3) Dusky-hued neonate

(4) Photosensitivity

\section{What is the bronze baby syndrome and which diseases should be differentiated from it?}

BBS, an unusual neonatal dyschromia, develops in jaundiced neonates following phototherapy and is characterized by a diffuse gray-brown pigmentation of the skin. ${ }^{1-3)}$ Bronze baby syndrome (BBS) is a rare condition that develops only in infants with elevated serum conjugated and unconjugated bilirubin levels; however, in BBS, conjugated bilirubin level is not always elevated. ${ }^{4)}$ Pigmentation can develop in various abdominal organs and body fluids, but the risk of kernicterus and central nervous system staining is controversial. ${ }^{3)} \mathrm{BBS}$ should be differentiated from gray baby syndrome, which is exclusively observed in neonates and young infants receiving high doses of chloramphenicol. ${ }^{4)} \mathrm{BBS}$ must also be differentiated from dusky-hued neonates with cyanosis.

Table 1. Patient's laboratory values and reference ranges

\begin{tabular}{|c|c|c|c|}
\hline \multirow[b]{2}{*}{ Laboratory test } & \multicolumn{2}{|c|}{ Patient values } & \multirow[b]{2}{*}{$\begin{array}{l}\text { Reference } \\
\text { range }\end{array}$} \\
\hline & $\begin{array}{c}\text { On } \\
\text { admission }\end{array}$ & $\begin{array}{l}\text { When baby got } \\
\text { gray-brown skin }\end{array}$ & \\
\hline Total bilirubin (mg/dL) & 34.2 & 16 & $\leq 12.0$ \\
\hline Direct bilirubin (mg/dL) & 1.6 & 1.9 & $0.3-1.0$ \\
\hline Hemoglobin (g/dL) & 12.8 & 7.7 & $15.0-24.0$ \\
\hline WBC $\left(/ \mathrm{mm}^{3}\right)$ & 16,740 & 9,470 & $9,100-34,000$ \\
\hline Platelet count (/mm³) & 386,000 & 159,000 & $\begin{array}{c}130,000- \\
450,000\end{array}$ \\
\hline Reticulocyte count (\%) & 9.07 & & $<0.1-1.3$ \\
\hline Albumin (g/dL) & 3.4 & 2.5 & $2.5-3.4$ \\
\hline AST/ALT (IU/L) & $43 / 17$ & $31 / 13$ & $6-40 / 24-95$ \\
\hline Direct Coombs' & $(+++)$ & & $(-)$ \\
\hline Indirect Coombs' & $(+++)$ & & $(-)$ \\
\hline Anti-E antibody & $(+++)$ & & $(-)$ \\
\hline Blood type & $\mathrm{A}, \mathrm{Rh}(+)$ & & \\
\hline Methemoglobin (\%) & 0.7 & 0.3 & $<1 \%$ \\
\hline ABGA & Nonspecific & Nonspecific & \\
\hline
\end{tabular}

Tandem mass spectrometry Nonspecific

WBC, white blood cell; AST/ALT, aspartate aminotransferase/alanine aminotransferase; ABGA, arterial blood gas analysis.

Received: 20 May, 2019, Revised: 12 September, 2019, Accepted: 18 September, 2019

Copyright $(\odot 2019$ by The Korean Pediatric Society

This is an open-access article distributed under the terms of the Creative Commons Attribution Non-Commercial License (http://creativecommons.org/licenses/by-nc/4.0/) which permits unrestricted non-commercial use, distribution, and reproduction in any medium, provided the original work is properly cited. 


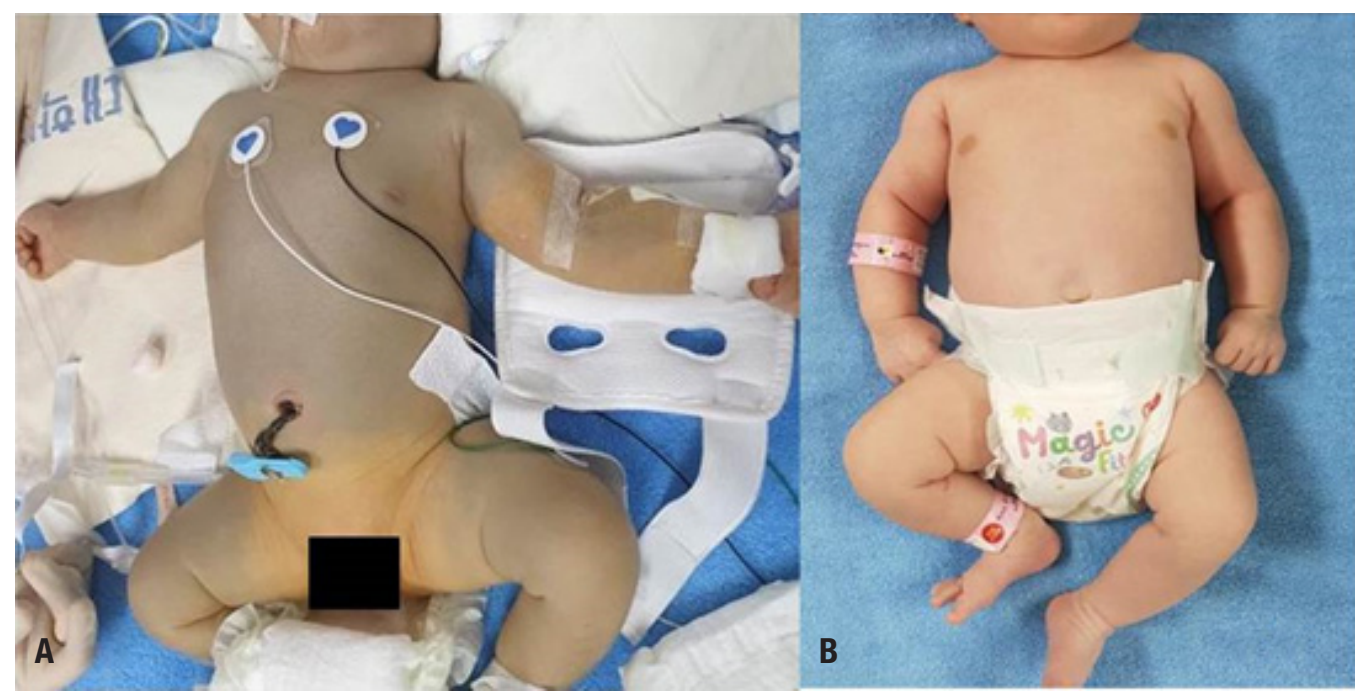

Fig. 1. (A) Newborn infant with significant jaundice and bronzing of areas exposed to phototherapy. Areas covered by the diaper and the intravenous line fixture did not show bronze discoloration. (B) Bronzing improved over the ensuing days, and skin color was normal at discharge.

\section{What causes BBS?}

An abnormal accumulation of the photoisomers of bilirubin may cause BBS. ${ }^{3)}$ The second suggested cause is the abnormal accretion of copper porphyrins, possibly resulting from erythroid and hepatic hemopoietic hyperactivity, as noted in hemolytic jaundice. ${ }^{3-8)}$ This is the most widely accepted cause of BBS. However, McDonagh ${ }^{9)}$ reported that bilirubin does not lead to photosensitization of copper porphyrins; therefore, porphyrin destruction is an unlikely cause. This finding was based on in vitro spectroscopic measurements. The accumulation of biliverdin, a metabolic precursor of bilirubin, has also been proposed as the cause of pigmentation. ${ }^{3,48}$ It is possible that all these 3 factors contribute towards the development of BBS. However, this has not yet been completely elucidated.

\section{How should BBS be treated?}

Phototherapy is usually discontinued when BBS develops. However, phototherapy-induced bronzing is a self-limiting process; thus, continuing the phototherapy may decrease bilirubin levels and the risk of exchange transfusion. Le and Reese ${ }^{3}$ suggested that development of BBS should not lead to suspension of the use of phototherapy for hyperbilirubinemia in infants with elevated conjugated bilirubin levels. Conversely, Peinado-Acevedo et al. ${ }^{10)}$ stated that the continuation of phototherapy presented a risk of cholestasis to newborns with BBS and recommended that it be suspended; however, phototherapy can be reinitiated when the direct bilirubin level decreases and cholestasis has resolved. It is not clear whether phototherapy should be continued or stopped in BBS. Therefore, an appropriate choice must be made based on the patient's condition.

\section{Patient outcome}

In our case, the intensive phototherapy was ceased for 4 hours to prevent progression of the discoloration. Once a slight decrease in pigmentation was noted, phototherapy was restarted to treat jaundice. Phototherapy was then continued for 24 hours and discontinued when the serum total bilirubin level decreased to $8.5 \mathrm{mg} /$ dL. The resolution of discoloration was observed over the following days (Fig. 1B). Hemolysis due to anti-E antibody did not progress further. The infant did not present any neurological symptoms, such as hypertonia with arching or seizures associated with kernicterus and magnetic resonance imaging findings of the brain were normal; however, hearing test results were abnormal. She was discharged 33 days after birth and will be followed up as an outpatient.

This study was approved by the Eulji University Hospital's Institutional Review Board (approval number: 2019-04-026). Written informed consent was obtained for publication from the patient's parent.

Answer: (2) Bronze baby syndrome

\section{Conflicts of interest}

No potential conflict of interest relevant to this article was reported.

Da Jeong Lee, MD, Woo Sun Song, MD, Seung Yeon Kim, MD, PhD Department of Pediatrics, Eulji University Hospital, Daejeon, Korea 
Corresponding author: Seung Yeon Kim, MD, PhD

Department of Pediatrics, Eulji University Hospital, 95 Dunsanseoro, Seo-gu, Daejeon 35233, Korea

Tel: +82-42-611-3391-2

Fax: +82-42-259-1111

E-mail:dunggiduk@eulji.ac.kr

https://orcid.org/0000-0002-7004-4821

\section{References}

1. Kopelman AE, Brown RS, Odell GB. The "bronze" baby syndrome: a complication of phototherapy. J Pediatr 1972;81:466-72.

2. Ashley JR, Littler CM, Burgdorf WH, Brann BS 4th. Bronze baby syndrome. Report of a case. J Am Acad Dermatol 1985;12(2 Pt 1): 325-8.
3. Le TN, Reese J. Bronze Baby Syndrome. J Pediatr 2017;188:301-301. e1.

4. Purcell SM, Wians FH Jr, Ackerman NB Jr, Davis BM. Hyperbiliverdinemia in the bronze baby syndrome. J Am Acad Dermatol 1987; 16(1 Pt 2):172-7.

5. Ottinger D. Bronze baby syndrome. Neonatal Netw 2013;32:200-2.

6. Hussain SA. Pulse oximetry interference in bronze baby syndrome. J Perinatol 2009;29:828-9.

7. Kar S, Mohankar A, Krishnan A. Bronze baby syndrome. Indian Pediatr 2013;50:624.

8. Rubaltelli FF, Da Riol R, D’Amore ES, Jori G. The bronze baby syndrome: evidence of increased tissue concentration of copper porphyrins. Acta Paediatr 1996;85:381-4.

9. McDonagh AF. Bilirubin, copper-porphyrins, and the bronze-baby syndrome. J Pediatr 2011;158:160-4.

10. Peinado-Acevedo JS, Chacón-Valenzuela E, Rodríguez-Moncada LL. Bronze baby syndrome, an unpredictable complication of phototherapy: a case report. Biomedica 2018;38:15-8. 